

Studies in Fungi 3(1): 73-78 (2018) www.studiesinfungi.org

ISSN 2465-4973

\title{
Article
}

Doi 10.5943/sif/3/1/9

Copyright $\odot$ Institute of Animal Science, Chinese Academy of Agricultural Sciences

\section{Ascobolus gomayapriya: A new coprophilous fungus from Andaman Islands, India}

\section{Niranjan $M$ and Sarma VV*}

Department of Biotechnology, Pondicherry University, Kalapet, Pondicherry-605014, India.

Niranjan M, Sarma VV 2018 - Ascobolus gomayapriya: A new coprophilous fungus from Andaman Islands, India. Studies in Fungi 3(1), 73-78, Doi 10.5943/sif/3/1/9

\begin{abstract}
Ascobolus is a very large genus among coprophilous fungi colonizing dung. There are very few workers who have explored dung fungi from India. During a recent trip to Andaman Islands, examination of cow dung samples revealed a new coprophilous fungus in the genus Ascobolus and the same has been reported in this paper. The present new species A. gomayapriya colonizes and grows on cow dung. A. gomayapriya is characterized by stalked, light-greenish-yellow apothecial ascomata, long cylindrical, short pedicellate asci with rounded apical caps, positive bluing reaction to Lougal's reagent, ascospores that are hyaline to pale yellow red, smooth, cylindrical, thickwalled with two layers, sparsely dotted verruculose surface, very thin crevices.
\end{abstract}

Key words - Ascomycetes - Dung fungi - Pezizomycetidae - Pezizales - Taxonomy

\section{Introduction}

Coprophilous fungi are an important part of the wildlife ecosystems as they help in recycling nutrients in animal dung in a saprophytic mode (Richardson 2001). Together with protozoa, myxomycetes, bacteria, nematodes and many insects, fungi are responsible for the breakdown of animal faeces, and for recycling the nutrients they contain. These are specialized fungi, able to withstand, and in many cases are dependent on, passage through an animal's gut before growing on the dung (Richardson 2003). Coprophily is a fairly common style of life in mycobiota, shared by most Ascobolus and Saccobolus species (Doveri 2014). The genus Ascobolus had been established by Persoon (1796) for Ascobolus pezizoides, a dung inhabiting cup-fungus, as it differed from species of Peziza in possessing clearly visible and far protruding coloured tips of ripe asci. After the establishment of Ascobolus in 1796 under Ascobolaceae, several species with coloured ascospores also were added to this genus (Van Brummelen 1967).

In a recent collection trip to Andaman Islands, cow dung sample having a cup fungus has been found near the NIOT (National Institute of Ocean Technology) regional campus, Port Blair, Andaman and Nicobar Islands, India. Upon microscopic examination of the sample it has been found to belong to Ascobolus. Since the taxon did not fit in any of the existing species it has been described as a new species in Ascobolus in this paper.

\section{Material and methods}

During the month of August, 2016 we collected cow dung sample near the National institute of oceanography (NIOT), Port Blair, South Andaman, Andaman \& Nicobar Islands, India beneath a 
big plantation area with Cocos nucifera (cocos), Areca catechu (local name = supari) and many other plants. The fungus was collected and transferred into small zip lock plastic bag, air dried overnight, and packed into new plastic bags for shipment to the laboratory for further processing. Before undertaking the microscopic examination, the fruit bodies were separated from the dung samples. Then they were examined under a Stereo Zoom microscope (Optika SZM-LED, Italy). The fruit bodies were cut with a razor and the spore constituents were transferred to a microslide mounted with stains like Lactophenol, Lactophenol Cotton Blue and Lougal's reagent. These slides were then examined under the Nikon ECLIPSE TiU upright microscope with DIC objectives fitted with Nikon DS-Fi2 digital camera, Japan to take photomicrographs. Measurements were taken with Nikon NIS-Elements-Imaging Software version 4.4 program, photoplates were made with Microsoft power point, and Adobe Photoshop version 7.0. Morphological identification was carried out by referring to various monographs and individual publications including (Van Brummelen 1967, Kirk et al. 2008, Pandey 2008, Melo et al. 2014). The herbarium material of the holotype was deposited at Ajrekar Mycological Herbarium (AMH), Agharkar Research Institute (ARI), Pune, India.

\section{Results}

\section{Taxonomy}

Ascobolus gomayapriya M. Niranjan and V.V. Sarma, sp.nov.

Fig. 1

Mycobank number: MB823982

Etymology - In Sanskrit gomaya means cow dung and priya means loving or fond of meaning a fungus loving to thrive on cow dung.

Holotype - AMH-9951

Saprobic on Cow dung. Sexual state: Ascomata 280-400 $\mu \mathrm{m}$, apothecial, single to aggregated, fleshy, stalked, glabrous, funnel shaped, light greenish-yellow coloured. Hymenium flat, hyaline become blue in Lougal's reagent, long tubular aseptate paraphyses. Excipulum thin loosely connected hyaline tissue composed of textura globulosa cells, excipulum ectale hyaline and became brown when it dried with globulosa-angularis cells. Paraphyses hyaline, tubular, aseptate, unbranched. Asci 125-155 X 15-19.5 $\mu \mathrm{m}(\overline{\mathrm{X}}=137.05$ X 16.6) $(\mathrm{n}=20), 8$-spored, unitunicate, long cylindrical, smooth-walled, rounded apical cap, short pedicel, deliquescent, immature asci become blue in Lougal's solution. Ascospores (24.9) 25.1-28.5× (11.7) 12.9- 15.7 (16.4) $\mu \mathrm{m}(\overline{\mathrm{X}} 26.6-15 \mathrm{X}$ 13.7) $(\mathrm{n}=25)$, overlapping uniseriate, rarely overlapping biseriate, hyaline when young, pale yellow to red at maturity, smooth, cylindrical, cemented in early stage and free when mature, thick-walled, with two layers, inner layer smooth, hyaline with circular depressions and the outer layer pale golden yellow with sparsely dotted verruculose on surface, with very thin crevices that turn into fissures and cease out from the ascospores. Asexual state: Not determined.

Known distribution - India

Material examined - INDIA, Andaman and Nicobar Islands, South Andaman, Port Blair, near

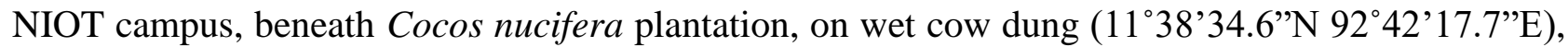
9 August 2016, M. Niranjan, Holotype AMH-9951, ARI, Pune, India.

Notes - The family Ascobolaceae comprises 129 species grouped in 6 genera (Kirk et al. 2008). The first world monograph on the genera Ascobolus and Saccobolus (Ascomycetes, Pezizales) was published by Van Brummelen (1967) who also reported 7 species from India. $A$. gomayapriya is characterized by stalked, light-greenish-yellow apothecial ascomata, long cylindrical, short pedicellate asci with rounded apical cap, ascospores that are hyaline when young, pale yellow to red at maturity, smooth, cylindrical, thick-walled with two layers, sparsely dotted verruculose surface, with very thin crevices. The species reported under the genus Ascobolus from India were: A. immersus from Patna, A. furfuraceus unknown place in India, A. denudalus from Uttarakhand, A. geophilus from Mussoorie Hills Uttarakhand, A. gollanii from Saharanpur-Garden manured soil, Uttar Pradesh, A. scatigenus Hyderabad, Punjab and Uttar Pradesh, A. indicus from 
Delhi (Sanwal 1953). Later, Pandey (2008) listed A. behniziensis from Kolhapur, Maharashtra on dung of Ox, A. crenulatus from Satara Maharashtra, on bird droppings, A. foliicola from Radhanagari, Maharashtra on dung, A. hawaiiensis in Kolhapur, Maharashtra, on dung, A. minutus in Karad, Maharashtra, A. sacchariferus, Kolhapur, Maharashtra, on buffalo dung. Altogether 13 species belonging to Ascobolus have been reported from India (Van Brummelen 1967, Kar \& Pal 1968, Khare 1976, Ghandge \& Patil 1988, Pandey 2008) (Table 1). So far no species of Ascobolus have been reported from Andaman Islands, India. This is the first report of a fungus belonging to Ascobolus from Andaman Islands and it has been found to be a new one. A dichotomous key is provided that delineates the new species from other closely related species of Ascobolus.

Table 1 A synopsis of dimensions of ascomata, asci and ascospores of different species of Ascobolus species reported from India.

\begin{tabular}{|c|c|c|c|c|c|}
\hline S.no & Species name & Ascomata & Asci & Ascospore & Reference \\
\hline 1. & $\begin{array}{l}\text { Ascobolus behnitziensis } \\
\text { Kirschst. }\end{array}$ & $\begin{array}{l}0.2-0.6 \times 10 \\
\mathrm{~mm}\end{array}$ & $\begin{array}{l}160-200 \times 17-23 \\
\mu \mathrm{m}\end{array}$ & $\begin{array}{l}20.5- \\
25.5 \times 11.5-14 \\
\mu \mathrm{m}\end{array}$ & $\begin{array}{l}\text { (Ghandge \& } \\
\text { Patil 1988) }\end{array}$ \\
\hline 2. & $\begin{array}{l}\text { Ascobolus crenulatus } \mathrm{P} \text {. } \\
\text { Karst. }\end{array}$ & $1-2 \mathrm{~mm}$ & $132 \times 11.5-13 \mu \mathrm{m}$ & $\begin{array}{l}11.5-13 \times 7-8.5 \\
\mu \mathrm{m}\end{array}$ & $\begin{array}{l}\text { (Ghandge \& } \\
\text { Patil 1988) }\end{array}$ \\
\hline 3. & $\begin{array}{l}\text { Ascobolus denudatus } \\
\text { Fr. }\end{array}$ & $1-2 \times 10 \mathrm{~mm}$ & $170-230 \times 16-23 \mu \mathrm{m}$ & $\begin{array}{l}(16-) 18-22(- \\
23) \times(8.5-) \\
9.5-11.5 \mu \mathrm{m}\end{array}$ & $\begin{array}{l}\text { (Thind \& } \\
\text { Waraitch 1974) }\end{array}$ \\
\hline 4. & $\begin{array}{l}\text { Ascobolus foliicola } \\
\text { Berk. \& Broome. }\end{array}$ & $1-2 \times 4-5 \mathrm{~mm}$ & $165-172 \times 18-22 \mu \mathrm{m}$ & $20 \times 10 \mu \mathrm{m}$ & $\begin{array}{l}\text { (Ghandge \& } \\
\text { Patil 1988) }\end{array}$ \\
\hline 5. & $\begin{array}{l}\text { Ascobolus furfuraceus } \\
\text { Pers. }\end{array}$ & $\begin{array}{l}0.4-0.8 \times 0.5- \\
5 \mathrm{~mm}\end{array}$ & $\begin{array}{l}\text { (120) } 180-250 \times \\
(20-) 24-30(-32) \mu \mathrm{m}\end{array}$ & $\begin{array}{l}\text { (16-) } 19-28(- \\
32) \times(9-) 10- \\
14(-16) \mu \mathrm{m}\end{array}$ & $\begin{array}{l}\text { (Van } \\
\text { Brummelen } \\
1967)\end{array}$ \\
\hline 6. & $\begin{array}{l}\text { Ascobolus geophilus } \\
\text { Seaver. }\end{array}$ & $\begin{array}{l}5-7 \times 0.5-1.0 \\
\mathrm{~mm}\end{array}$ & $132-150 \times 21-23 \mu \mathrm{m}$ & $\begin{array}{l}18-22 \times 10-13 \\
\mu \mathrm{m}\end{array}$ & $\begin{array}{l}\text { (Ghandge \& } \\
\text { Patil 1988) }\end{array}$ \\
\hline 7. & $\begin{array}{l}\text { Ascobolus gollanii } \mathrm{P} . \\
\text { Hennings }\end{array}$ & & & - & $\begin{array}{l}\text { (Hennings } \\
1901)\end{array}$ \\
\hline 8. & $\begin{array}{l}\text { Ascobolus hawaiiensis } \\
\text { Brumm. }\end{array}$ & $0.2-0.25 \mathrm{~mm}$ & $100-115 \times 25-32 \mu \mathrm{m}$ & $13-8.5 \mu \mathrm{m}$ & $\begin{array}{l}\text { (Ghandge \& } \\
\text { Patil 1988) }\end{array}$ \\
\hline 9. & $\begin{array}{l}\text { Ascobolus immersus } \\
\text { Pers. }\end{array}$ & $0.5-1 \mathrm{~mm}$ & $\begin{array}{l}350-600(700) \times 50- \\
85(100) \mu \mathrm{m}\end{array}$ & $\begin{array}{l}30-50(60) \times 16- \\
33 \mu \mathrm{m}\end{array}$ & $\begin{array}{l}\text { (Ghandge \& } \\
\text { Patil 1988) }\end{array}$ \\
\hline 10. & $\begin{array}{l}\text { Ascobolus indicus } \\
\text { Sanwal. }\end{array}$ & - & 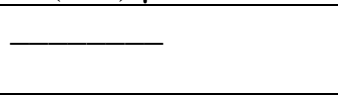 & - & (Sanwal 1953) \\
\hline 11. & $\begin{array}{l}\text { Ascobolus minutus } \\
\text { Boud. }\end{array}$ & $\begin{array}{l}0.2-0.4 \times 0.3- \\
1.2 \mathrm{~mm}\end{array}$ & $\begin{array}{l}140-170 \times 13-14 \\
\mu \mathrm{m}\end{array}$ & $\begin{array}{l}12.5-15 \times 7-8 \\
\mu \mathrm{m}\end{array}$ & $\begin{array}{l}\text { (Ghandge \& } \\
\text { Patil 1988) }\end{array}$ \\
\hline 12. & $\begin{array}{l}\text { Ascobolus } \\
\text { sacchariferus Brumm. }\end{array}$ & $1-3 \times 1 \mathrm{~mm}$ & $149-165 \times 18-20 \mu \mathrm{m}$ & $\begin{array}{l}16-20 \times 6.5-8 \\
\mu \mathrm{m}\end{array}$ & $\begin{array}{l}\text { (Ghandge \& } \\
\text { Patil 1988) }\end{array}$ \\
\hline 13. & $\begin{array}{l}\text { Ascobolus scatigenus } \\
\text { (Berk. \& M.A. Curtis) } \\
\text { Brumm. }\end{array}$ & $1.2 \mathrm{~cm}$ & $150-180 \times 18-24 \mu \mathrm{m}$ & $\begin{array}{l}27-33 \times 6.5-8 \\
\mu \mathrm{m}\end{array}$ & $\begin{array}{l}\text { (Leelavathy \& } \\
\text { Flower 1981) }\end{array}$ \\
\hline
\end{tabular}

\section{Discussion}

Species belonging to Ascobolus are mostly recorded on various animal dungs but rare on cow dung (Van Brummelen 1967). In the present study a taxon that has characters of the genus Ascobolus has been recorded on cow dung and upon comparing with other species has been found to be new and is named as Ascobolus gomayapriya. Ascomata of A. gomayapriya are greenishyellow in appearance which is similar to ascomata of A. lineolatus, A. immersus, A. mancus, A. elegans, A. furfuraceus, A. michaudii, and A. crenulatus. While A. furfuraceus is different from A. gomayapriya in having larger ascomata, $A$. crenulatus is different in having sessile ascomata when 
compared to A. gomayapriya, Ascospores of A. mancus have similar dimensions as that of $A$. gomayapriya, while the ascospores of $A$. michaudii were found to be smaller. However, asci with an apical cap is present in $A$. mancus which is lacking in A. gomayapriya. Other similar species such as $A$. roseopurpurascens, $A$. furfuraceus $A$. lineolatus vary by having striated ascospores and lack dotted verruculose surface. Ascospores of $A$. immersus have striated and dotted verruculose surface but are smaller in size when compared to A. gomayapriya. A. elegans has similar but larger ascospores when compared to A. gomyapriya. While A. immersus has been reported on dung from various animals excepting cow, A. elegans has been reported only from horse dung. Based on the above morphological differences a new species $A$. gomayapriya has been proposed to be accommodated in the genus Ascobolus.

\section{Key to the different species of Ascobolus that are closely related to A. gomayapriya reported from India}



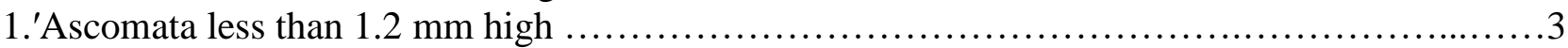

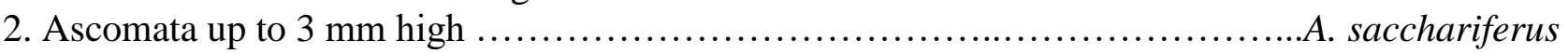

2.' Ascomata 5-7 mm high .................................................. geophilus

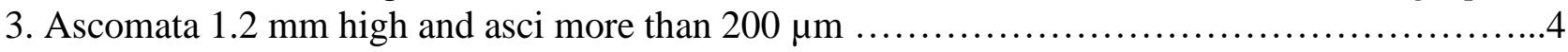

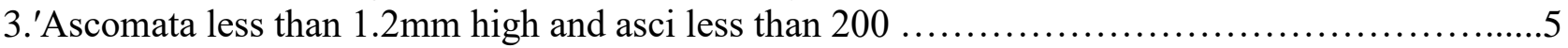

4. Asci 170-230×16-23 $\mu \mathrm{m}$.................................................... denudatus

4.' Asci (120) 180-250 × (20-) 24-30(-32) $\mu \mathrm{m}$....................................... furfuraceus

5. Ascomata $1.2 \mathrm{~mm}$ high and asci up to $200 \mu \mathrm{m}$ high ............................ behnitziensis

5.' Ascomata $1.2 \mathrm{~mm}$ high and asci less than $200 \mu \mathrm{m}$ high .................................6

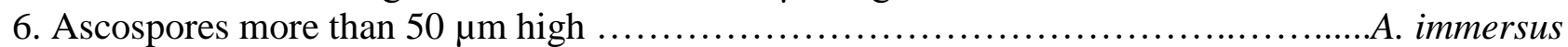

6.' Ascospores less than $50 \mu \mathrm{m}$ high ...........................................................

7. Ascospores 27-33×6.5-8 $\mu$ m episoprium with one or two warts...................... scatigenus

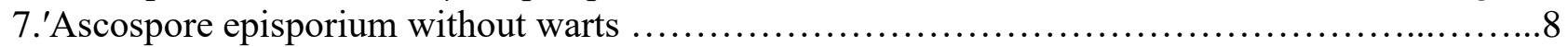

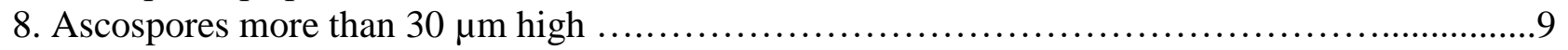

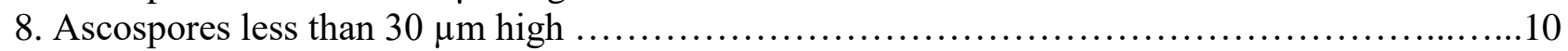

8.' Ascospores episoprium smooth or granular ........................................... elegans

9. Ascospores episoprium granular surface ..................................... hawaiiensis

9.' Ascospores episoprium with striae ................................................... 11

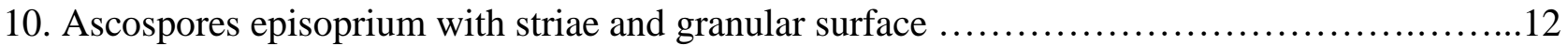

11. Ascospores episoprium longitudinal anastomosing striae ............................ foliicola

11.' Ascospores episoprium with longitudinal and rarely anastomosing striae .............. minutus

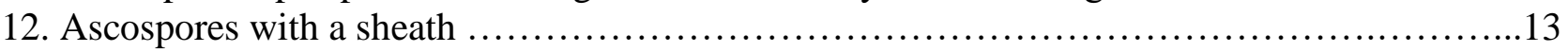

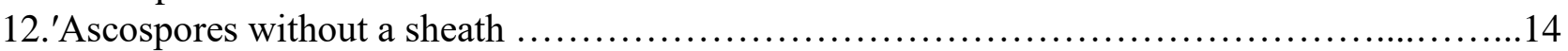

13. Ascospores episoprium with longitudinal, rarely anastomosing striae and unilateral sheath

A. crenulatus

13.'Ascospores episoprium with longitudinal, anastomosing striae and unilateral sheath

14. Ascospores episoprium with multiple short striae and granular A. sacchariferus

14.' Ascospores episoprium with one or two long striae and granular

A. geophilus

A. gomayapriya 




Fig. 1 - Ascobolus gomayapriya (AMH-9951, holotype). a Ascomata on cow dung. b Asci bluing in Lougal's reagent. c Excipulum. d Paraphyses. e-h Asci. i-p Ascospores. Scale bars $-\mathrm{b}=50 \mu \mathrm{m}$, $\mathrm{d}, \mathrm{e}, \mathrm{h}=20 \mu \mathrm{m}, \mathrm{c}, \mathrm{f}-\mathrm{g}, \mathrm{i}-\mathrm{p}=10 \mu \mathrm{m}$.

\section{Acknowledgements}

Authors are thankful to the Science and Engineering Research Board (SERB), Ministry of Science and Technology, Govt. of India for funding a project (SERB/SB/SO/PS/18/2014 dt.19.5.2015). M. Niranjan is thankful to SERB, DST, Government of India for the award of the fellowship. The Department of Biotechnology, Pondicherry University is thanked for providing the facilities. 


\section{References}

Doveri F. 2014 - An update on the genera Ascobolus and Saccobolus with keys and descriptions of three coprophilous species, new to Italy. Mycosphere 5, 86-135.

Ghandge DN, Patil MS. 1988 - Studies on Discomycetes IV-Genus Ascobolus. Indian Phytopathology 41, 177-182.

Hennings P. 1901 - Fungi Indiae orientalis II. cl. W. Gollan a. 1900 collecti. Hedwigia 40, 323342.

Kar A.K, Pal KP. 1968 - Some Coprophilous Discomycetes of Eastern Himalaya (India). Mycologia 60, 1086-1092.

Khare KB. 1976 - Two Ascobolus species from India. Current science 45, 385-386

Kirk PM, Cannon PF, Minter DW, Stalpers JA. 2008 - Dictionary of the Fungi CABI. Wallingford, UK.

Leelavathy KM, Flower L. 1981 - Additions to South Indian Agaricales-I. Kavaka 9, 31-33.

Melo RF, Miller AN, Santiago AL, Maia LC. 2014 - The genera Ascobolus and Saccobolus (Ascobolaceae, Pezizales) in Brazil. Mycosphere. 5, 790-804.

Pandey A. 2008 - Ascomycetes of Peninsular India. Scientific Publishers (India).

Persoon CH. 1796 - Observationes mycologicae 1, 1-116.

Richardson MJ. 2001 - Diversity and occurrence of coprophilous fungi. Mycological Research $105,387-402$.

Richardson MJ. 2003 - Corophilous fungi. Field Mycology 4, 41-43.

Sanwal BD. 1953 - Contributions towards our knowledge of Indian Discomycetes II. Two new operculate Discomycetcs. Sydowia 7, 200-205.

Thind KS, Waraitch KS. 1974 - The Pezizales of India-XV. Proceedings of national academy of science india 44: 27-35.

Van Brummelen J. 1967 - A world-monograph of the genera Ascobolus and Saccobolus (Ascomycetes, Pezizales). Persoonia. - Supplement 1-260. 